\title{
折れ曲がり街路空間の期待感と物的要因の関係 \\ THE FUNCTIONAL RELATIONS BETWEEN ANTICIPATION AND THE SPACE SHAPE OF CURVED STREETS
}

\author{
松本 直司*, 瀬田惠 之** \\ Naoji MATSUMOTO and Shigeyuki SETA
}

\begin{abstract}
While strolling along a street, you may feel drawn to the space ahead of you. We have defined such dynamic attractiveness as "anticipation" and intend to elucidate the functional relations between anticipation and the space shape of curved streets. Using a visual simulator, we recorded 135 VTR images of street scale models and asked 16 subjects to estimate their magnitude of anticipation. From this we were able to extract physical factors such as the ratio of invisibility and height $/(\text { width })^{2}$ and incorporate them to formulate an equation that enables us to calculate the degree of anticipation.
\end{abstract}

\section{Keywords : Anticipation, Curved streets, Physical factors, Invisibility, Height/(width)}

期待感, 折れ曲がり空間, 物的要因, 不可視領域, スケール補正高さ幅員比

\section{1.はじめに}

建築群の空間形態や空間構成は，人間の心理に様々な影響を及ぼ す。広場でくつろぐ人には，包容感や安定した静的魅力を与えるで あろう。一方，街路路地で歩行する人には，先の空間に「行って みたい」「導かれる」「吸い込まれる」といった動的な魅力を与える であろう。本研究ではこれらの空間の魅力のうち，後者に相当する 人間を前方の空間に誘い込むような動的な魅力を期待感と定義し， 期待感を与える典型的な街路空間構成である折れ曲がり空間を対象 として，その空間形状を示す物的変量と期待感の関係を明確化する ことを目的とする。

街路の期待感に関して Gordon Cullen(1961)"は，期待感 (anticipation) をこちらとあちら（here and there)の概念と結びつけ て, here はすでに知っている空間領域, there は here に対する向こ うの，知らない，無限の，神秘的な，隠された空間領域として意味 付けている。Cullenは先が折れ曲がっている街路空間の写真を例に して, 折れ曲がりの手前を here, 曲がったあたりから先の隠れてい る部分まで含めた空間領域を there として示している。thereは anticipation の可能性を持つ空間として捉えられ，anticipationは here と there の関係性でその強弱が決定されることを示唆している。

また Edmund $\operatorname{Bacon}(1968)^{2)}$ はデザインの本質として anticipation をとらえ，町の中心に向かうときに出現した衝撃的な建物の色彩が， 次に現れるであろう色彩への期待感を高めている例をあげている。
この場合，他と異なる際立った色彩が町の中心に近くなった目印と なり，今後現れるであろう色彩を予見させるのである。

これまで空間の動的魅力に関して，筆者らは 1973 年に空間の視 賞的連続性という観点より，計画住宅地において連続感を与える空 間の抽出実験を行った。 ${ }^{3)}$ その結果，前方の空間が折れ曲がってい ること，真っ直ぐに空間が続いていること，トンネルなどの空間の 分節を通して先の空間の雾囲気を感じること，レベル差によって空 間が分けられるが先の空間の䨌囲気が伺えることなど，5つの連続 感を与える空間パターンが存在すること，連続感が遠近感，期待感 などと類似の概念であることを明らかにしている。

その後 1995 年には, 計画住宅地から街路空間の研究へと発展さ せ，空間の魅力を連続感ではなく，期待感というより身近な概念で とらえて研究を行った。4)，5) その結果, 期待感の要素として「上り 坂・下り坂」「カーブ・折れ曲がり」などの道路形状要素，「側方壁 面」,「並木」などの垂直要素，「遠景・空」などの景観要素を抽出して いる。期待感の意味としては，「不可視空間への意識」や空間の「連 続感」，その他に「リスム感がある」,「遠近感が強い」,「囲まれ感が 強い」ことなどを抽出している。さらに期待感のある空間構成とし て12の空間構成を抽出し期待感の強度を比較している。

本研究では, Gordon Cullen が here and there に関連させた anticipationに極めて近い概念として期待感を捉え，これまでの研究 成果をふまえて，期待感のある街路空間構成のひとつである折れ曲
$*$ 名古屋工業大学社会開発工学科建築系 教授・工博

** 飛島建設技術研究所 工修
Prof., Dept. of Architecture and Civil Engineering, Nagoya Institute of Technology, Dr. Eng.

Tobishima Corporation, Technological Research Institute, M. Eng. 
がり空間を対象として，縮尺模型空間を用いた実験により空間形状 と期待感の関係を関数化したのでここに報告する。

\section{2. 折れ曲がり街路空間における期待感}

途中で角度を持って水平方向に届折している街路の状態を折れ曲 がりとし，その状態にある空間を折れ曲がり空間とする。折れ曲が り空間はこれから姿を現すであろう見えない空間（以下では不可視 空間と呼ぶ）への意識を誘う典型的な形態であり，基本的には物的 変数として街路幅員 $(d)$, 折れ曲がり角度 $(\theta)$, 街路側面の壁面高 さ $(h)$ という 3 変数によって空間が決定される。

ここでは,折れ曲がり空間における期待感と $\theta$ との関係を中心に， 物的変数 $d, h$ との関係を分析するとともに，現地評価実験で抽出 した主要な 10 理由項目 ${ }^{* 2}$ の内,「囲まれ感」,「遇続感」,「不可視空 間への意識」の 3 項目と期待感の相関関係を明確化するための実験, 分析を行った。

2.1 对象空間パターンの選定

2.2.1 折れ曲がり角度と期待感

既往研究で行った 8 地区での現地実験*3におおて抽出した期待感 のある空間構成 218 例のうち，折れ曲がり空間である 29 例につい て，その折れ曲がり角度を測定して集計した結果を図 1 に示す。

折れ曲がり角度 $\theta$ が $31^{\circ} \sim 40^{\circ}$ の場合が最も場面数が多く, 次 いで $21^{\circ} \sim 30^{\circ}$ となっている。 $60^{\circ} \sim 70^{\circ}$ になると場面数が極 端に減少している。実験地区である8地区の街路バターンを見ても 特に $\theta$ が $31^{\circ} \sim 40^{\circ}$ に集中している訳ではなく，むしろこの範囲外 のより大きな角度の方が多く存在している。従って折れ曲がり角度 としては $11^{\circ}$ から $60^{\circ}$ の範囲が期待感のある角度であることがわか る。

\section{2 .2 実験対象パターン}

実験対象パターンとして折れ曲がり角度 $\theta$ は $60^{\circ}$ 以内の 9 パ夕 ーンとした。さらに，他の变数である街路幅員 $d$ とその街路側面の 壁面高さ $h$ にも期待感は影響されると考えられるために, $d$ を $4 \mathrm{~m}$ ， $8 \mathrm{~m}, 12 \mathrm{~m}$ の 3 通りとし, 壁面高さ/幅貝比 $(h / d)$ を $0.5 \sim 2.0$ の 間で 5 段階に変化させた。従って，実験対象は合計 $9 \times 3 \times 5=135$ パターンとした。(図 2)

\section{2 実験方法}

実験は実験対象パターンについて，折れ曲がり部分から手前と向 こう側, それそれ $40 \mathrm{~m}$ の区間について $1 / 50$ スケール模型を作成し た。実験には，街路模型の手前側から折れ曲がり部分までの歩行を 想定し，速度 $1.6 \mathrm{~m} / \mathrm{min}$ て 30 秒間，視点高さ $3 \mathrm{~cm}$ から，模型空間 知覚シミュレータ*4によってVT R 撮影した映像を用いた。

被験者は名工大学部学生・大学院生の計 16 名で, 2, 3 名ずつ 6 グループに分けて行った。実験は 2 台の TV モニターを使用し，そ れそれ評価の基準となる標準刺激の空間と, 被験者グループことに ランダムな順序にした比較刺激空間を提示した。

期待感の評価方法は，標準刺激を 100 とするマグニチュード推定 法 (ME 法) と,「囲まれ感」,「連続感」,「不可視空間の意識」の3 理由項目についての視知覚的強度の 7 段階評定である。実験は平成 9 年 10 月 27 日〜同 30 日に行い, 各パターンの提示時間は 30 秒で， 実験時間は各グルーブとも途中休䕀を 2 回とり，約 1.5 時間であっ た。

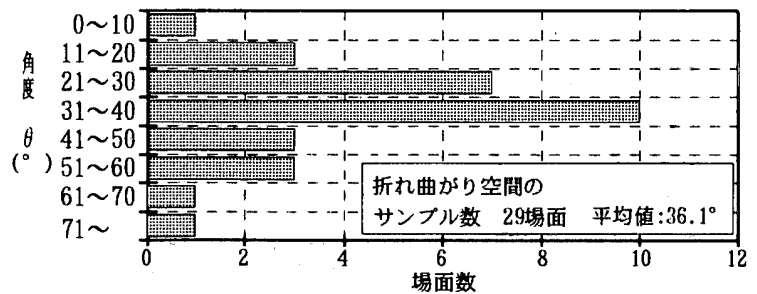

図 1 現地調查における折れ曲がり角度と指摘場面数

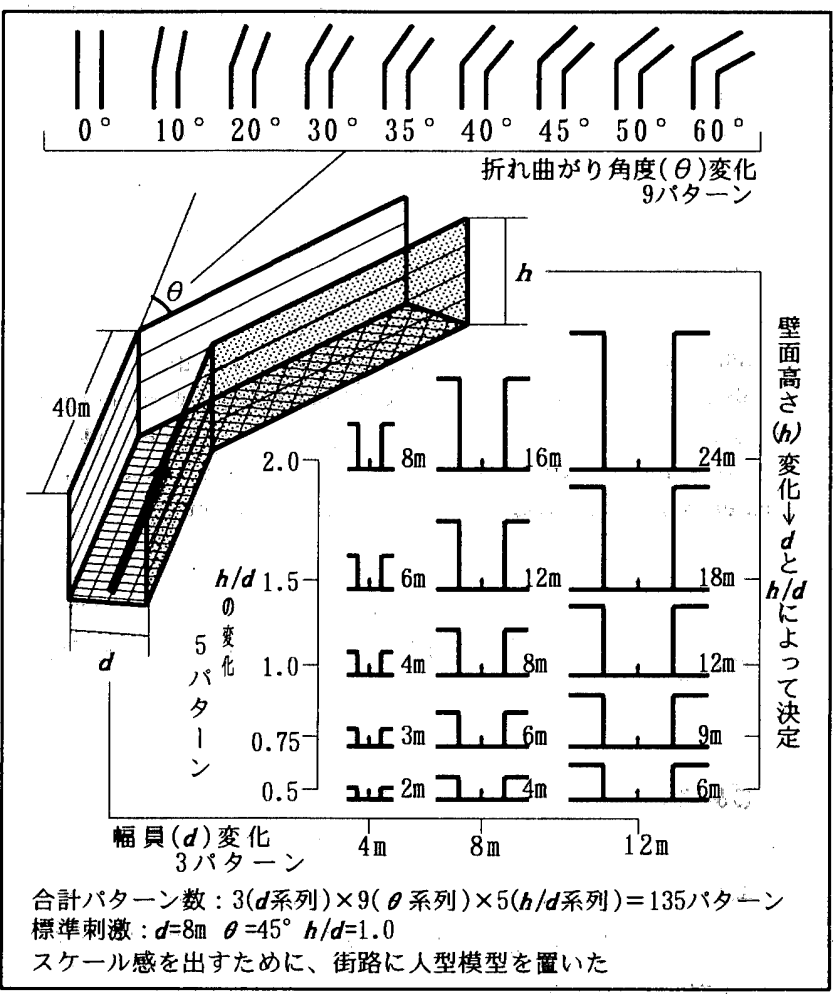

図2 シミュレータ実験と実験対象パターン

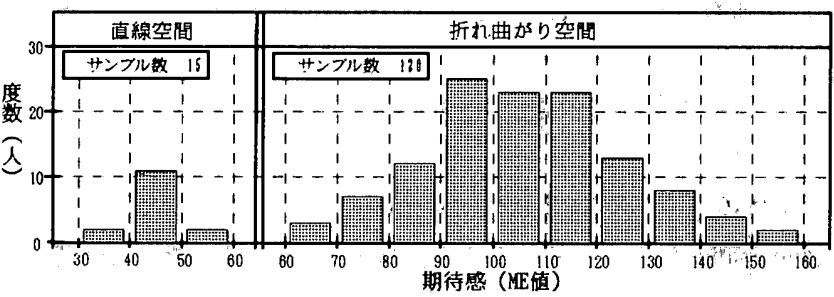

図 3 期待感の度数分布

\section{3 空間形態と期待感の関係}

実験結果における期待感の強さ（ME 值）の幾何平均值を求め, その度数分布を図 3 に示す。折れ曲がり空間における期待感の ME 值は 60 〜 160 の範囲に分布している。 $\theta=0$ である直線形態の街路 ではすべて 60 末満であり，折れ曲がり空間と比較すると期待感が 弱い。期待感の最頻值としては $90 \sim 100$ で $100 \sim 110$ 及び 110 〜 120 も頻度が高く, 折れ曲がり空間での結果で判断するとやや比較 刺激より大きな值を示している。ちなみに ME 值の幾何平均值は直 線空間で 47.0, 折れ曲がり空間で 104.4 , 全体で 70.4 である。実験 における標準刺激は折れ曲がり空間でのほほ平均值であったことが わかる。 
期待感の強さと物的変数である $\theta, d, h$ との関係を見るために ME 值を記号化して図 4 に示す。期待感の強さは $\theta, d, h$ によって变 化し，その傾向は $d$ が $4 \mathrm{~m}$ のときに顕著で $\theta$ が $10^{\circ}$ の時に最も大 きくなっている。幅貝 $d$ が $8 \mathrm{~m}, 12 \mathrm{~m}$ と増加すると $\theta$ が小さい 10 。の場合に期待感が小さく, $20^{\circ}$ や $30^{\circ}$ で最も大きくなり,さら に $\theta$ が大きくなるとまた小さくなっている。

\section{4 期待感と理由項目の関係}

図 5 は理由項目別の期待感の強度を示している。

「囲まれ感」では，h/d の值との相関が高く，評価の大きさを示 寸記号が上下に分離している。それでも，実験空間全体では期待感 との相関が 0.46 であり大きいとはいえないものの，折れ曲がり空 間の場合の実験結果に限定すると 0.93 となり相関が高い。

「連続感」は期待感と異なり直線空間での評価が高いために期待 感との相関は低いが，折れ曲がり空間での結果に限定すると期待感 との相関は 0.94 と高い。

「不可視空間の意識」は，連続感と異なり直線空間で評価が低く なっている。実験空間全体の場合と折れ曲がり空間に限定した場合 ともに相関が高く，それそれ $0.99 ， 0.98$ となっている。「不可視空 間の意識」が折れ曲がり空間における期待感の重要な理由項目とな っている。

\section{3、期待感評価による被験者の分類}

各被験者における期待感の評価傾向をとらえるため，被験者 16 名を変量, 実験対象空間 135 パターンをサンプルとし, ME 值を用 いた主成分分析を行った。その結果，各軸の固有值の大きさと寄与 率から判断して 2 因子軸が得られた。（図6）因子負荷量による被 験者と因子得点による実験対象空間の布置図を，それそれ図 7, 図 8 , 図 9 に示す。対象空間での折れ曲がり角度の大きさ別に記号化 した図 8 において，それそれの記号がほぼ縦に並んで布置されてい る。このことは，第 I 軸が角度の相違によって変化する軸であるこ とを示している。「角度変化」の軸とする。図 4 における幅員別の期 待感の大きさと比較すると第 I 軸の記号別の大きさ変化が図中の期 待感の大きさ変化とよく一致している。

図 9 では，どの幅員においても第II軸方向に $h / d$ の大きさを表す 記号が並んでいる。すなわち，h/d の大きさが第II軸の值を決定し ている。第II軸は「幅員・壁面高さ」と解釈される。図 7 で全被験者 は第 I 軸の正の方向に布置されて, 寄与率は第 I 軸 $44 \%$ と高く, 期待感は角度変化の影響が大きいことがわかる。第II軸は，被験者 が正負にわたって分布しており，被験者によって判断傾向が異なる ことを示している。

そこで, 被験者を期待感の判断傾向によって分類するために, 被

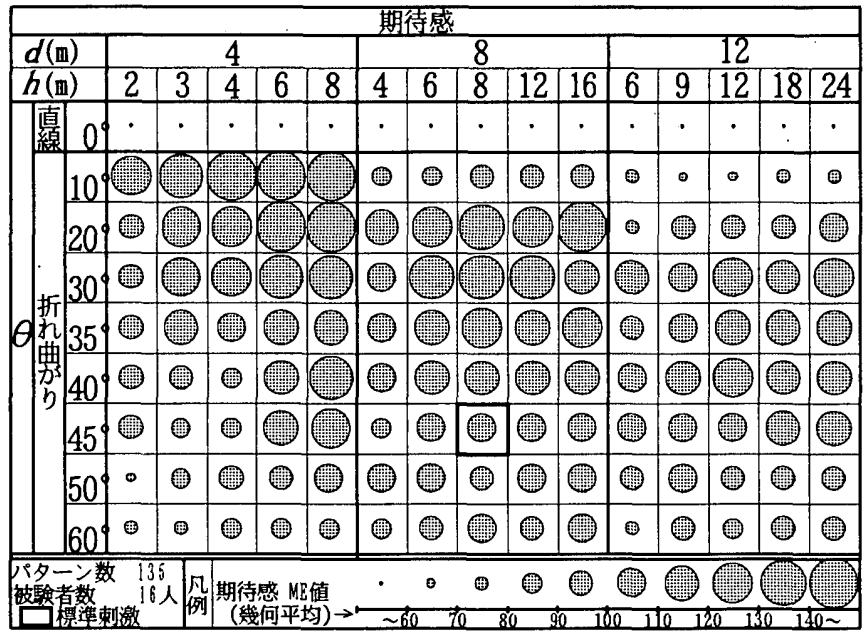

図4 物的変数の変化と期待感

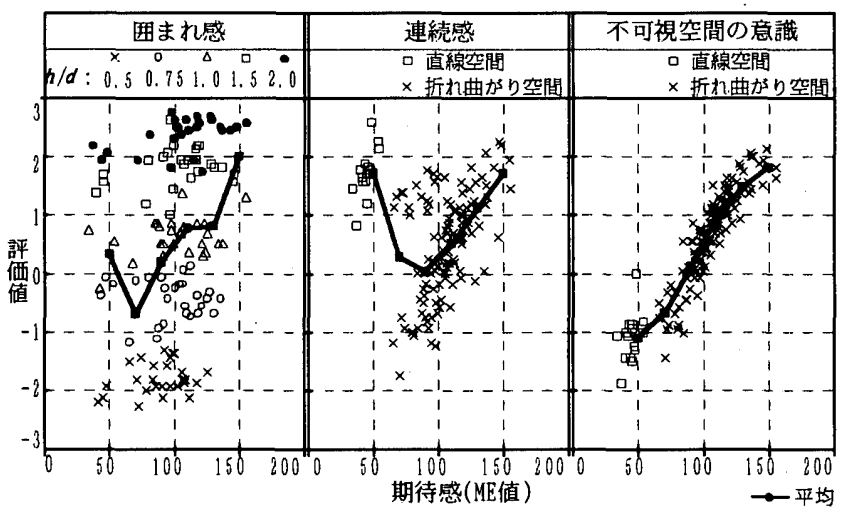

図 5 期待感の強さと理由項目評価

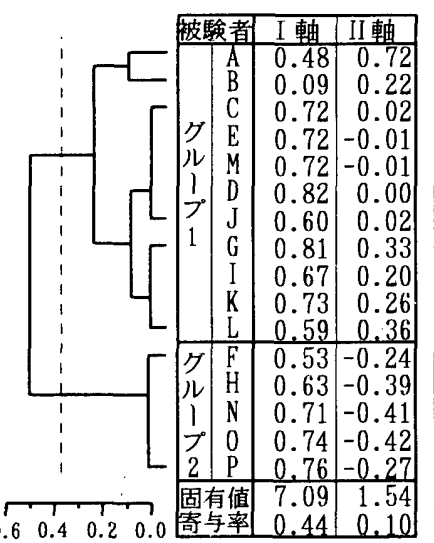

図 6 被験者別主成分負荷量

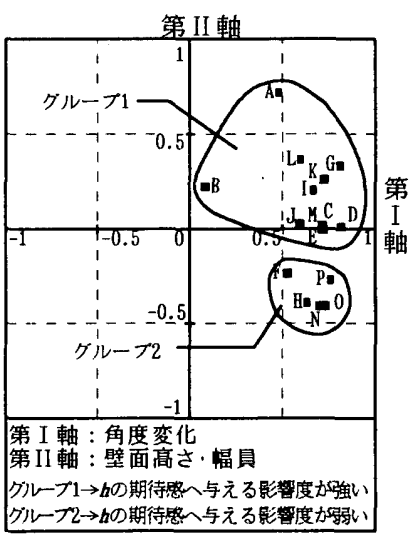

図7 被験者の布置図

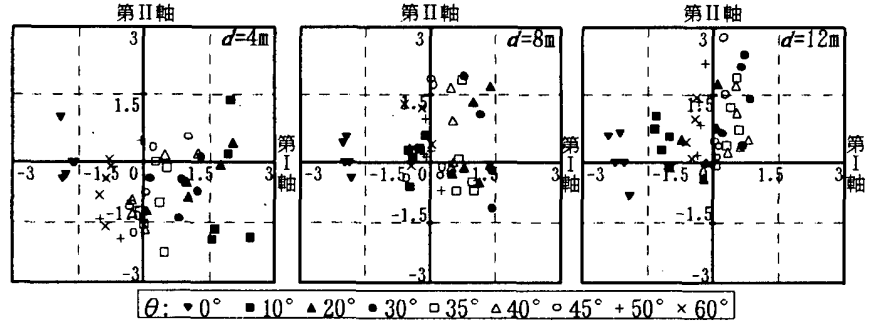

図 8 実験対象空間の主成分得点（角度別）

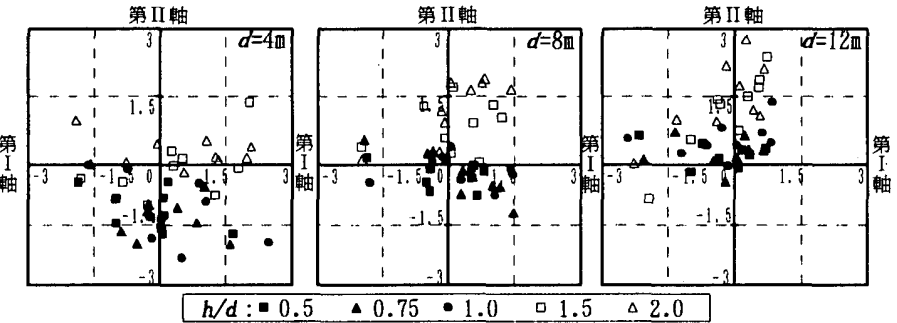

図 9 実験対象空間の主成分得点 $(h / d)$ 
験者間の主成分負荷量による 2 軸空間におけるユークリッド距離を もとに,クラスター分析（WARD 法）を行った。その結果, 被験 者は大きく2グループに分類された。図10は，グループ別，街路幅 貝別に $h / d$ と期待感の関係を示している。グルーブ 1 でばどの幅員 においても h/d の增加とともに期待感が上昇しているが，グルーフ 2 では横這いか不規則な変化である。従って, グループ 1 は期待感 に対して街路の立体要素である壁面高さの影锌を受けており，グル 一プ2はその影響が小さいことがわかる。

以下では, 対象空間を立体的にとらえ，かつ被験者の多いグル一 プ1を対象として，期待感と物的変数の解析を進める。

\section{4. 期待感と物的変数の関係}

図11 は，街路の折れ曲がり角度と期待感の関係を街路幅員別に 示している。どの場合においても $0^{\circ}$ が最も期待感が小さく，ピー クとなる角度まで上昇して極値にいたりその後減少する。期待感が 最も強くなる角度が, $d=4 \mathrm{~m}$ のとき $10^{\circ}, d=8 \mathrm{~m}$ のとき $20^{\circ}, d=12 \mathrm{~m}$ のとき 30 と幅貝によって異なっている。幅員が狭い方が小さな 角度で期待感が強くなり，角度が大きくなると期待感は弱くなる。 また, 幅貝が小さい方が期待感の最大值が大きく, 各幅貝の最大值 は直線空間の期待感の 2 倍〜 2.5 倍になっている。以上より, 期待 感と折れ曲犁り角度の変化との間に法則性が存在することがわか る。

次に図 12 の期待感と $h / d$ の関係から, h/d が 0.5 から 2.0 の範囲 では，h/d が大きくなると期待感も強くなり，その変化量は幅貝が 狭い方が大きいことがわかる。すなわち，狭い幅貝の方が広い幅員 より $h / d か ゙$ 期待感に及ぼす影響が大きいといえる。

\section{5. 期待感の予測}

実験パターンにおける評価の幾何平均值の対数を目的変数，物的 変量を説明変数として重回帰分析を行い,期待感の予測式を求める。 5.1 説明変数の選択

まず，d， $\theta, h / d$ および，図11において期待感は $\theta$ の增加に対 してはじめ増加してその後減少するため, 二次関数である $\theta^{2}$ の項 を加えた 4 説明変数で重回帰分析を行った。しかし，結果は重相関 係数が 0.81 とそれほど高くなく，期待感の最大值をもたらす $\theta$ も 幅貝による变化が見られなかった。幅買が狭いほど壁面高さの影響 が大きいという実測值の特性を示しておらず，回帰式モデルとして は不適当であった。

そこで，主成分分析から得た「角度変化」と「幅員・壁面高さ」 の 2 軸に注目し，角度の影響を考慮した変数と $h / d$ を考虑した変数 を作成した。すなわち，図 13 に定義した「前方可視壁面長さ $L\lrcorner$ ， 図 14 に定義した「スケール補正高さ幅貝比s」である。 $s$ は h/d だけ では定義しきれない断面形態を空間の大きさで補正したものであ る。 $L$ については説明变数として， $\theta=0$ の時に分母の $\sin \theta=0$ となり $L=\infty$ となるために逆数の $1 / L$ とし, $1 / L^{2}$ を加えた 2 変数と， $s$ による重回帰分析を行った。しかし，その結果は重相関係数 $\mathrm{R}=$ 0.78 となり適合度は十分とは言えなかった。また，幅貝が広くなる と期待感を最大とする $\theta$ が $60{ }^{\circ}$ を越えてしまい, 回兴モデルして も不適当であった。たたしし， $s$ については，幅貝が狭いときに $h / d$ による変域が大きくなっていて実測值の性質を良く反映しており，

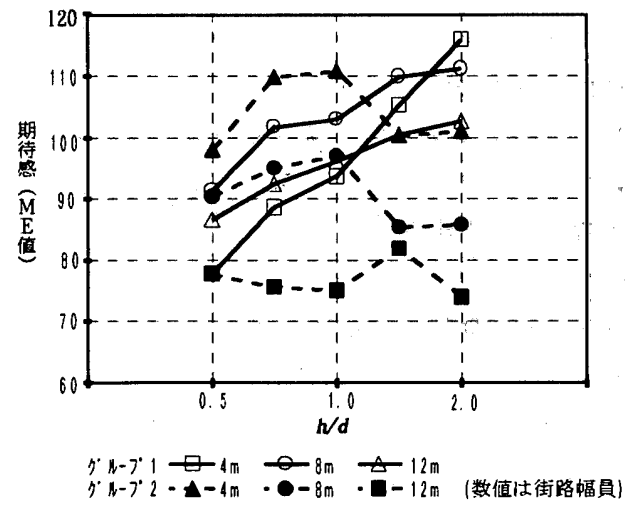

図10 グルーブ別，幅員別の期待感の評価とh/dの関係

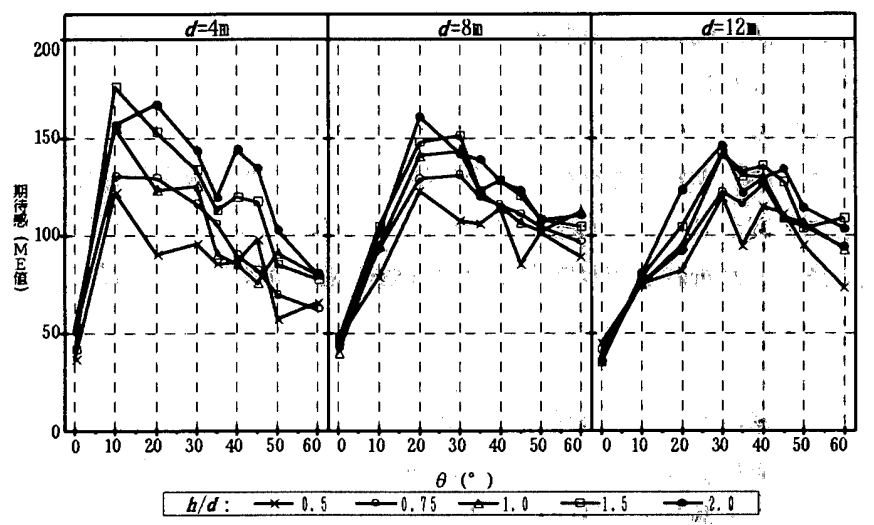

図11 幅員別の期待感と角度の関係

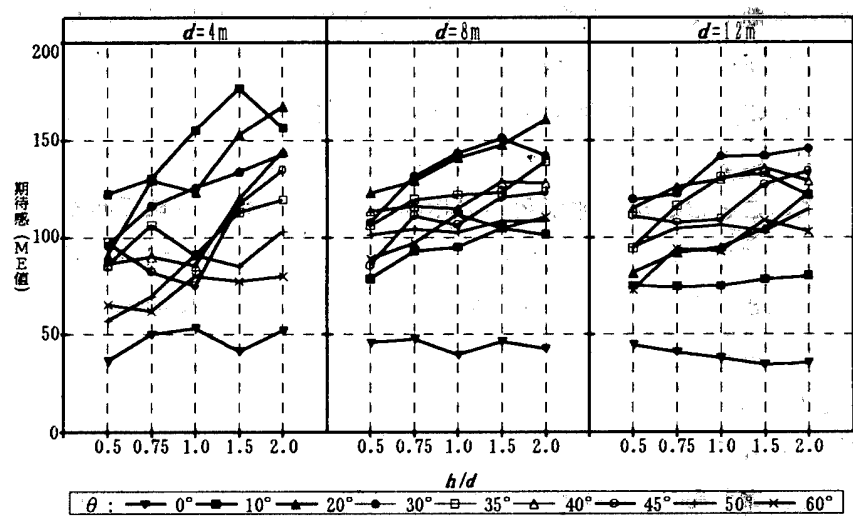

図12 幅貝別の期待感と $h / d$ の関係

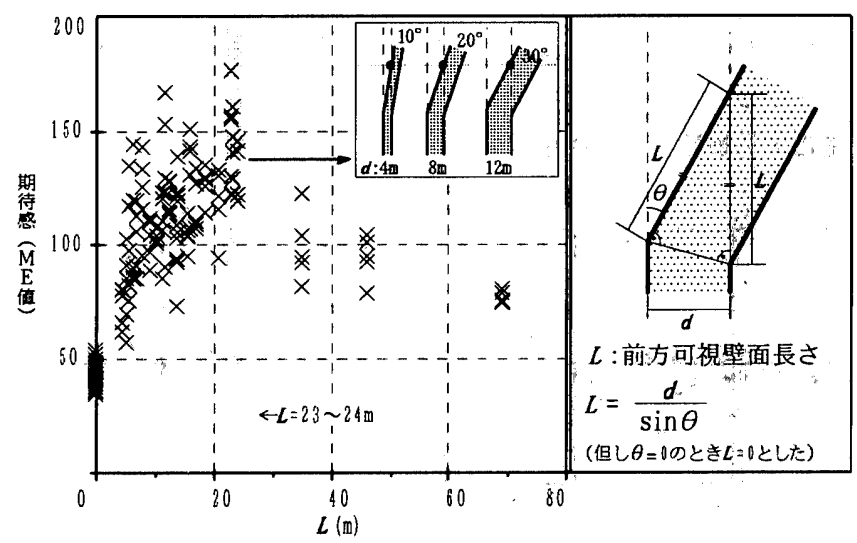

図13＼cjkstart前方可視壁面長さ $L$ と期待感の関係 
説明变数として採用した。

回㷌モデルの適合度を高めるために，理由項目で期待感と強い相 関を示した「不可視空間への意識」に着目し，壁面の長さではなく 面積を考慮した説明変数を加えることにした。空間領域を限定する ための值として，図 13 に示したように各幅貝において期待感を最 大とする $L$ が $23 \sim 24 \mathrm{~m}$ であることを考虑し， $d=12, \theta=30^{\circ}$ の時 の $L=24 \mathrm{~m}$ を用いて, この範囲を近距離として図 15 に示す近距離 空間内における不可視領域率 $r$ を定義した。従って， $L$ は $24 \mathrm{~m}$ 内 と $24 \mathrm{~m}$ 以上とでは場合分けが必要となっている。分析の結果，表 1 に示すように重相関係数 $\mathrm{R}=0.95$ ，決定係数が 0.91 と高い精度 の回帰モデルを得た。補正不可視領域率 $r^{\prime}$ を表 1 . のように定める と, 期待感 (対数值) は, $\theta$ と $d$ による期待感の強さ曲線を意味す る $r^{2}{ }^{2}$ 項に $s$ 項および定数項を加えた $Y=-3.86 r^{2}+0.95 s+4.77$ となり， 期待感 $(A)$ は $A=e^{y}$ で表される。

\section{2 回帰式による期待感}

折れ曲がり角 $\theta$ と期待感の関係を図 16 に示す。幅貝別に比較す ると，角度が小さい場合には狭い空間の方が期待感が強く，角度が 大きくなると広い空間の方が期待感が強くなっている。これは幅員 が狭い空間では，折れ曲がり角度が大きいとき閉鎖性が強くなるた めと考えられる。期待感の最大值を幅貝別に比較すると，幅員が狭 い空間の方が最大值が大きく，空間の㹟さによる適度な閉鎖性が期 待感を強めている。次に期待感を最大とするときの $\theta$ を $\theta \max$ と し, $\theta \max$ を求めた。回㷌式から $r=0.55$ のとき $\theta \max$ となり, 図 17 に示す式が得られる。つまり，近距離空間の半分程度が見え ない空間において期待感が強くなり，幅貝が広くなると $\theta$ max も 大きくなる。また， $\theta \max$ における期待感と $h / d$ および $d$ の関係を 図 18 に示す。期待感は，幅貝が狭いとき，h/dの大きい空間で期待 感が最も強くなり,幅員が狭い空間では h/dによる変域が大きく,h/d が強く期待感に影響を及ほすといえる。期待感と物的変数の関係を まとめた結果を図19に示す。

\section{6.まとめ}

以上の分析結果をまとめると次の通りである。

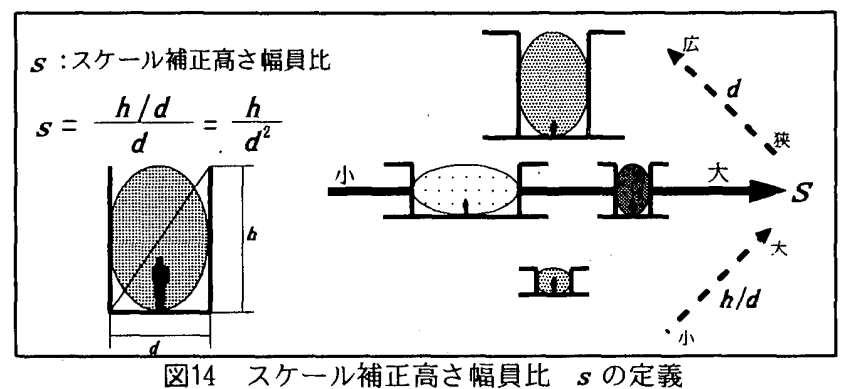

図14 スケール補正高さ幅員比 $s$ の定義

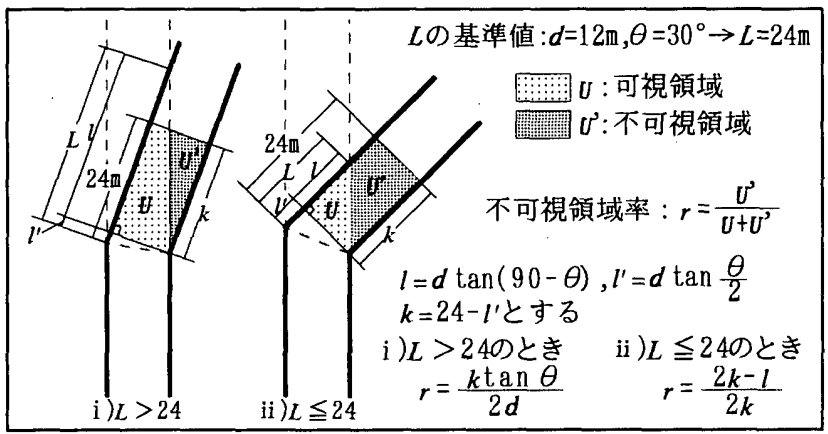

図15 不可視領域率 $r$ の定義

表 1 重回帰分析の結果

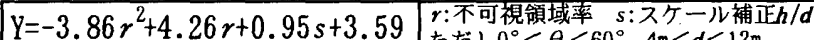
補正不可視領域率: $r=r-0.55$ とすると $\rightarrow \mathrm{Y}=-3.86 r^{2}+0.95 s+4.77$ 期待感 $A=\mathrm{e}^{\mathrm{Y}}$ (e:自然对数) ただし $0^{\circ}<\theta<60^{\circ}, 4 \mathrm{~m}<d<12 \mathrm{~m}$ 重相関係数 R 0.95 決定係数 $\mathrm{R}^{2} \quad 0.91$ $F_{0}=424.10>F(3,131,0.01)=3.93 よ b$ 有意水準 $1 \%$ で有意

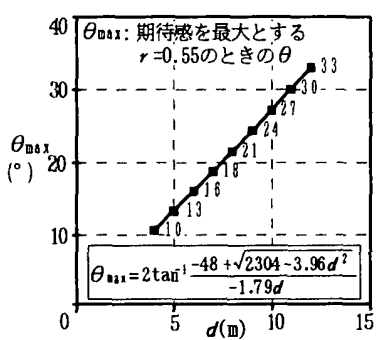

図17 $\theta$ maと幅貝の関係

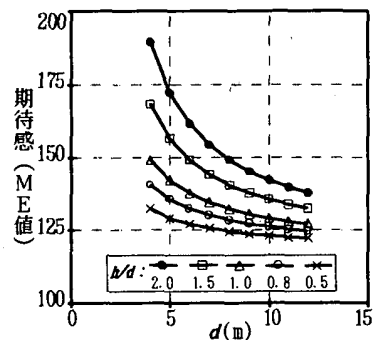

図18晒的における期待感 の予測と物理量の関係

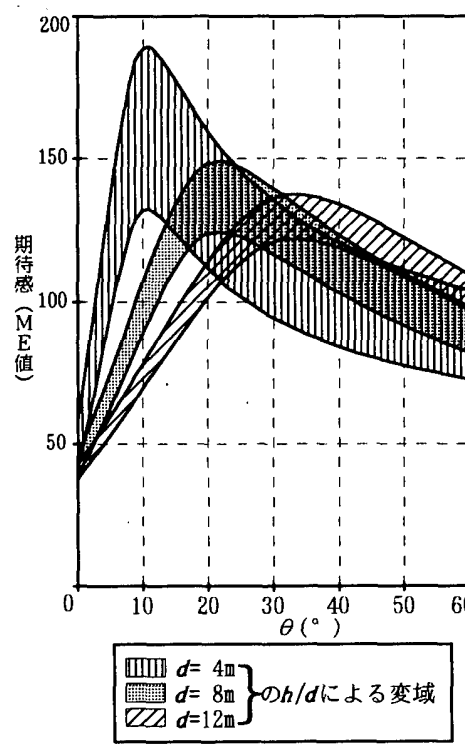

図16 回州式による $\theta$ と期待感の関係

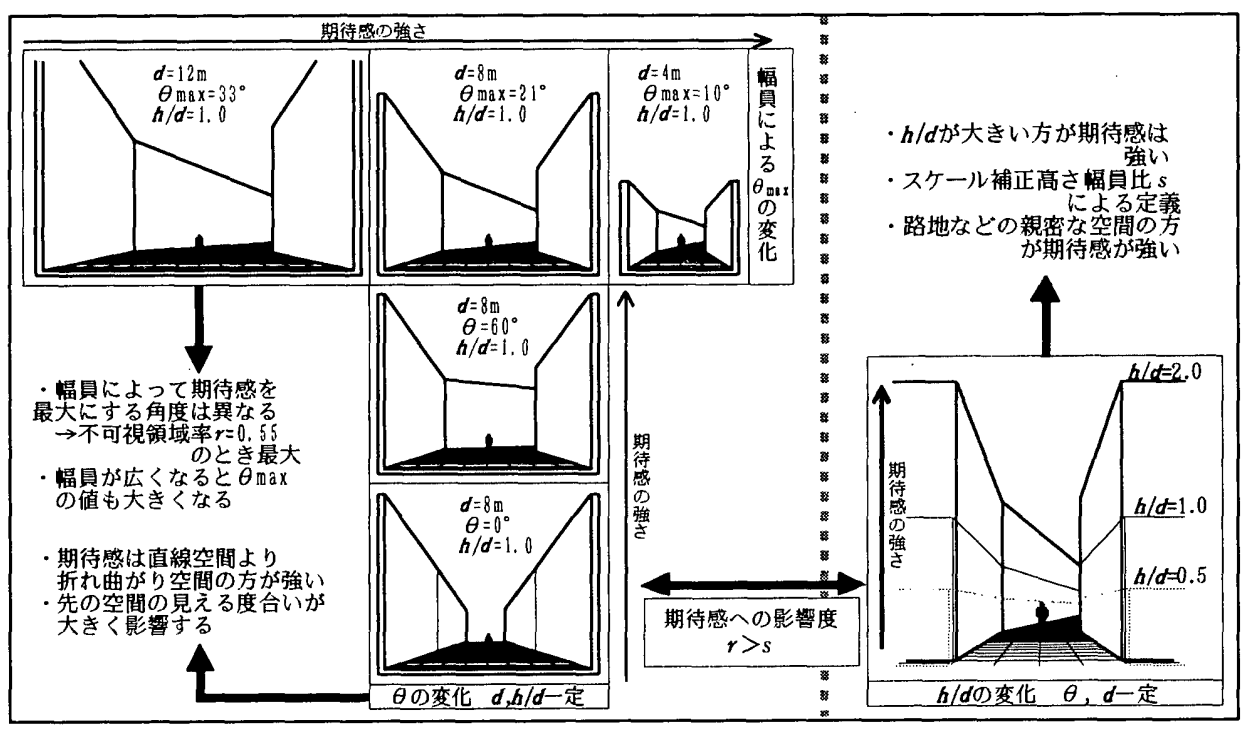

図19 期待感と物理量の関係 
(1)期待感は不可視空間への意識や連続感などが大きく起因する。(2) 期待感は直線形態より，折れ曲がり形態の方が強い。(3)折れ曲がり 空間の期待感は幅員によって期待感を最大にする角度が異なる。(4) 折れ曲がり空間における期待感の回帰式を求めた結果, 期待感は不 可視領域率とスケール補正高さ幅員比で説明可能である。(5)折れ曲 がり空間の期待感は不可視領域率が半分程度で，かつ路地のような ヒューマンスケールな空間のとき最も強くなる。

期待感はもともと空間の質に関係する。前方に楽しそうな状況か 存在すれば空間形態のいかんに関わらず，見てみたい，行ってみた いという期待感が生ずる。しかし，どんな魅力的な状況であっても， その状況がすべて把握された時には期待感は消滅する。期待感は人 間の好奇心や探求心と関係するもので，完全に把握できない，楽し そうな，何かありそうな状況において生ずる。

本研究では単純化した折れ曲がり空間の模型を用いており，空間 で生ずる内容による期待感ではなく空間の形態及びその関係性すな わち空間構造により生ずる期待感を対象にしている。分析により得 られた期待感の予測式は，重相関係数が高く当てはまりがよいこと を示しているが，これは見えない空間領域と見えない空間を予感さ せる空間領域を関数化できたことが重要であると考えられる。また， 側面の壁面高さを街路復員との比で表現したことも良い結果へとつ ながった。しかし，この予測式をそのまま現実の空間に適用しよう とするといくつかの疑問が残る。不可視領域率の計算において $24 \mathrm{~m}$ という定数を用いたところである。 $24 \mathrm{~m}$ とは芦原（1975）"によれ ば街路において建物か1 件 1 件区別できる距離 20〜30 mに当ては まり，高橋ら (1984) $)^{8)}$ のテータによれば人の顔が識別できる距離で ある。1/50の縮尺模型のV T R 映像による実験テー夕で，このよ うな単位のある数値を用いることが適合度を増すと言うことは驚き である。確かにこれまでに何度も模型によるシミュレー夕映像の有 効性については検証を行ってきて確かめられてはいる*が，視点の 高さ $1.5 \mathrm{~m}$ と模型内に圈かれた人型模型が空間の大きさを示すもの であり，どこまでこの数值の信頼性があるかはこれからの研究を待 たなくてはならない。いずれにしても，この数值の近辺に期待感を 解くカギが隐されていることを予見させる予測式である。
謝辞

本研究にこ協力いたたいた、平成 9 年度名エ大大学院博士前期課 程修了の小柳英治氏（東畑建築事務所勤務）に謝意を表します。

注

*1 本論文は1998年度日本建築学会東海支部研究報告集に発表した内容（参 考文献11)を加筆修正したものである。

*2 参考文献4)において期待感の理由項目として(1)不可視空間への意識 (2) 速続感 (3)リスム感 (4)方向性 (5)統一感 (6)光と影の対比 (7)遠近感 (8)誘目性 (9)妿囲気の良さ (10囲まれ感䚮抽出されている。

*3 文献4)，5)に拉いて, 槏々な用途の8地区を選定し, 被験者（名工大学 部学生・院生延へ26名）に自由に探索してもらい，期待感を感した場面 を写真に撮らせ，その地点と方向を地図上に記入させた。

*4 1996年に開発したビジュアルシミュレータであり，被験者がヘッドマウ ンテッドを装着して自由に見たい方向を钼察し，ノフ操作により移動し たい方向に自由に行くことのできるコンビュータ制御のシミュレーショ ンシステムである。詳紐は，参考文献 6 ) を参照されたい。本実験では， 一定方向に一定速度（1/50スケールにおいて 80 m/ninに相当する速度） で移動させて実験用V T R 映像として撮影した。

*5 グループ 2 については被験者数が 5 名で少数なため今回の分析では除い ている。グルーブ 2 は壁面高さhの影䇺が少ないグループ判断される ため、期待感は平面の特性変数のみで予测されることが期待される。

*6 参考文献 9)，10）を参照。

\section{参考文献}

1) Gordon Cullen(1961):The Concise TOWNSCAPE. The Architectural Press.

2) Edmund N. Bacon(1968): Design of Cities.The Viking Press, Inc.

3）谷口汎邦, 松本直司：建筑の空間構成に関する研究 その 1 (都市住宅地 における空間の分析），日本建築学会関東支部研究報告集，pp.177 180, 1974

4）小柳英治, 松本直司: 期待感を与える空間構成とその要因, 日本建築学 会大会学術講演梗概集，pp.697 698，1996.9

5) Naoji Matsumoto,Eiji Koyanagi,Shigeyuki Seta: Physical and Mental Factors of Anticipation in the Streetscape, pp.283 286, MERA97

6）瀬田, 松本他：知覚行動直結型ビジュアルシミュレータの開発, 日本建 築学会技術報告集, No.4, pp.92 96, 1997.3

7) 芦原舸信 : 外部空間の設計, 彰国社, 1975.1

8）高橋研究室編：かたちのデータファイル，彰国社，1984.2

9）松原，松本：景観シミュレーション手法の有効性に関する研究, 日本都 市計画学会学術研究論文集, No.26, pp.385 390, 1991

10)松本, 山本, 山下, 瀨田, 谷口: 模型空間知覞評価メティア.（シミュレ 一夕）の有効性, 日本建築学会計画系論文報告集, No.432, pp89 97, 1992.2

11)松本直司, 瀬田患之: 折れ曲がり街路空間の期待感と物的要因の関係, 日 本建築学会東海支部研究報告集, No.37,pp.645 648,1999.2 